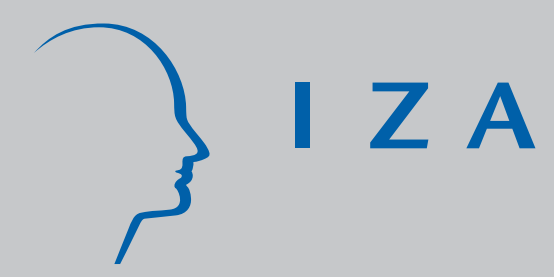

IZA DP No. 891

From Welfare to Work: Evaluating a

Proposed Tax and Benefit Reform

Targeted at Single Mothers in Sweden

Lennart Flood

Elina Pylkkänen

Roger Wahlberg

October 2003 


\title{
From Welfare to Work: Evaluating a Proposed Tax and Benefit Reform Targeted at Single Mothers in Sweden
}

\author{
Lennart Flood \\ Göteborg University and IZA Bonn \\ Elina Pylkkänen \\ Göteborg University \\ Roger Wahlberg \\ Göteborg University
}

Discussion Paper No. 891

October 2003

\author{
IZA \\ P.O. Box 7240 \\ D-53072 Bonn \\ Germany \\ Tel.: +49-228-3894-0 \\ Fax: +49-228-3894-210 \\ Email: iza@iza.org
}

\begin{abstract}
This Discussion Paper is issued within the framework of IZA's research area Evaluation of Labor Market Policies and Projects. Any opinions expressed here are those of the author(s) and not those of the institute. Research disseminated by IZA may include views on policy, but the institute itself takes no institutional policy positions.
\end{abstract}

The Institute for the Study of Labor (IZA) in Bonn is a local and virtual international research center and a place of communication between science, politics and business. IZA is an independent, nonprofit limited liability company (Gesellschaft mit beschränkter Haftung) supported by Deutsche Post World Net. The center is associated with the University of Bonn and offers a stimulating research environment through its research networks, research support, and visitors and doctoral programs. IZA engages in (i) original and internationally competitive research in all fields of labor economics, (ii) development of policy concepts, and (iii) dissemination of research results and concepts to the interested public. The current research program deals with (1) mobility and flexibility of labor, (2) internationalization of labor markets, (3) welfare state and labor market, (4) labor markets in transition countries, (5) the future of labor, (6) evaluation of labor market policies and projects and (7) general labor economics.

IZA Discussion Papers often represent preliminary work and are circulated to encourage discussion. Citation of such a paper should account for its provisional character. A revised version may be available on the IZA website (www.iza.org) or directly from the author. 
IZA Discussion Paper No. 891

October 2003

\section{ABSTRACT \\ From Welfare to Work: Evaluating a Proposed Tax and Benefit Reform Targeted at Single Mothers in Sweden}

In this paper we propose a tax and benefit reform to increase the working hours and to decrease the welfare participation of single mothers in Sweden. We have access to highquality tax and income data, and use a detailed tax-benefit program to generate precise budget-sets. We formulate and estimate a structural, static model of labor supply and welfare participation. The results suggest that labor supply among single mother households in Sweden is quite elastic, and that there is self-selection into welfare. The proposed reform would generate welfare-gains for virtually everyone in the sample, yet would be revenue neutral.

JEL Classification: J22, I38

Keywords: $\quad$ single mothers, labor supply, welfare participation, tax and benefit reform

Corresponding author:

Lennart Flood

Department of Economics

Göteborg University

Box 640, SE 40530

Göteborg

Sweden

Tel.: +46317731331

Fax: +46 317731043

Email: Lennart.Flood@economics.gu.se 


\section{Introduction}

The Swedish government has officially declared a goal of reducing Social Assistance

(SA) by half and increasing the rate of employment to $80 \%$ during the years 1999

2004. ${ }^{1}$ Since 1997 there has in fact been a sharp decline in SA for the whole

population, but a much slower decline for single mothers. Single mothers also have

large disincentive effects; for example, the net financial benefit for unemployed single

mothers of going to work is almost negligible. ${ }^{2}$

During the 1990s, the United States (U.S.) and the United Kingdom (U.K.) made major changes in many of the tax and transfer programs that affect single mothers. The main purpose of these reforms was to increase work incentives by reducing high marginal tax-rates. Similarly, the Swedish welfare system was the target of a number of reforms in the 1990s. However, Sweden has relied more on broad and general coverage, less on discretionary and targeted systems. Instead of eliminating nationwide eligibility and payment rules, as was done in the U.S. when AFDC was replaced with TANF in $1996,{ }^{3}$ Sweden eliminated any regional variation. Since 1998 uniform SA rules has been implemented.

In the U.S. and U.K., the main tool for reducing high marginal tax-rates has been targeted tax credits. Sweden, on the other hand, abolished a targeted tax-deduction for single mothers in 1991, in favor of a general basic deduction. Effective tax-rates on

\footnotetext{
${ }^{1}$ The SA target is measured by whole-year full-time equivalent; i.e. the number of recipients, compensation level, and their duration on SA matters. The employment target refers to $80 \%$ of individual's aged 20-64.

2 According to a report from the Swedish Ministry of Finance (Eklind et al. 1997), the net replacementrate for single mothers is about $90 \%$.

${ }^{3}$ See Blank (2002) for a review of the latest and most important changes in U.S. welfare programs.
} 
low-incomes were reduced generally. Thus not just for single mothers or working families with children. The deduction applies to everyone with taxable income.

There have been few studies on the combined effects of taxes and benefits on single mother's labor supply behavior and welfare participation. Most of the existing work concerning the disincentive effect of transfer programs has focused on the labor supply response of single mothers to changes in the U.S. Aid to Families with Dependent Children (AFDC) program, Levy (1979) and Moffitt (1986). ${ }^{4}$ Recently this literature has been extended to include the impact of the combination of cash and inkind benefits on single mother's labor supply behavior, Moffitt (1992), Keane and Moffitt (1998). The most recent and relevant studies for our purpose, are for the U.K. Blundell and Hoynes (2003), Duncan and Giles (1998) and for the U.S. Meyer and Rosenbaum (2001), indicate strong incentive effects from tax credits. The broadening of the tax credit seems to have had a major effect, increasing labor force participation and reducing welfare participation. In Sweden there has been only one study Andrén (2003), again revealing strong incentive effects.

The purpose of this paper is to propose and to evaluate the effects of, a reform targeted at single mothers, designed to increase labor-market participation as well as hours of work, to reduce welfare-dependence, and at the same time to be more or less self-financed. This reform is inspired by the U.S. and U.K. "from welfare to work" reforms, but is adapted to the Swedish welfare system. The main ingredient in this proposed reform is a combination of reduced taxes, reduced SA, and the already decided "maxtaxa" reform (reduced childcare fee).

\footnotetext{
${ }^{4}$ In August 1996, AFDC (the primary benefit program for low-income households) was replaced with the Temporary Assistance for Needy Families (TANF) block grant.
} 
The tool used for the analysis here is a structural discrete static model of labor supply and welfare participation. The discrete method for labor supply estimation has a number of advantages over continuous methods. It is uncomplicated to deal with nonlinear income taxes so that coherency conditions do not have to be imposed a priori Van Soest (1995). The preference-model is structural so that economic theory can be tested. It is possible to include preference-heterogeneity in the model, and it is straightforward to take into account multiple taxes and benefits in the budget-set.

Following Moffitt (1983), Hoynes (1996), and Keane and Moffitt (1998), we assume that there is a negative side effect associated with receiving SA. Further, this disutility from welfare participation was assumed to be separable, to allow for possible nonparticipation by eligible households. Finally, we allowed for unobserved heterogeneity in a very flexible way, without imposing a parametric structure, by using a semi-parametric method built on Heckman and Singer (1984).

The data used for this study is the 1999 wave from the Swedish Longitudinal Individual Data (LINDA). LINDA is completely based on register-information, and thus provides high-quality tax and income data. It is very important in a study such as this to have high-quality data, not only because there tends to be serious underreporting of welfare participation in traditional survey-data, but also because it allows one to obtain very precise budget-sets for different hours of work combinations. Furthermore, by using register-information on wages as opposed to self-reported wages, potential problems with measurement errors in wages can be reduced. 
To generate net income for each household, and different combinations of hours of work and welfare participation, we used a modified version of FASIT, a tax-benefit program designed at Statistics Sweden and the Swedish Ministry of Finance. FASIT contains very precise information on income tax rules, eligibility-rules for a number of welfare programs, and childcare fees, thus allowing us to generate accurate budgetsets.

The results suggest that a $1 \%$ wage increase corresponded to an average increase in hours of work of $0.62 \%$ suggesting that the labor supply of single mother households in Sweden is quite elastic. We found a negative covariance between SA and labor supply, implying self-selection into welfare.

When the model was used to simulate the likely behavioral responses to the introduction of the tax and benefit reform, we found a substantial increase in working hours. On average, working hours increase by $5 \%$ and disposable income by $7 \%$. Further, $6 \%$ of single mothers changed their working hours, SA participation decrease by more than $40 \%$, and the cost of SA decreased by $50 \%$.

We found potential welfare-gains for almost everyone in the sample. On average, Equivalent Variation (EV) in relation to before-reform disposable income was $6.6 \%$ for the whole sample. However, there was considerable variation across households, relative $\mathrm{EV}$ for the first income quartile was almost twice that of the third. The most important effect of our reform was the increase in working hours for low-income households. In the first income quartile there was an average increase of almost $40 \%$. 
Governmental revenues and expenditures were evaluated, and the proposed tax and benefit reform were more or less self-financed, due to the damatic reduction in cost of SA.

The next section presents the main features of the Swedish income tax and benefit systems and the following section describes the proposed tax and benefit reform.

Section 4 presents the economic model and empirical specification, while section 5 describes the data used. Section 6 presents the results, while Section 7 summarizes and draws conclusions.

\section{Income taxes and means-tested welfare programs in Sweden}

\subsection{Income taxes in Sweden}

The Swedish income tax system consists of two parts, a municipal tax-rate and a national tax-rate, on both earned and unearned income. Every resident must file an income tax return. The individual is the taxation-unit and income taxes are independent of marital status.

The municipalities have flat tax-rates, which differ between municipalities: The average municipal tax-rate in 1999 was $31.51 \%$, with a minimum of $26.25 \%$ and a maximum of $34.64 \%$. The national tax on earned income is progressive, with three income-brackets in 1999. For an income up to SEK 219,300 there was a zero national tax-rate; there was a $20 \%$ tax on incomes from SEK 219,300 to SEK 360,000, and a $25 \%$ tax on incomes above that.

Even though most taxpayers only pay municipal tax, there was some variation in 
marginal tax-rate due to variation in the basic deduction (see Table 1). Figure 1 shows how both the marginal and average tax-rates varies with taxable earned income. The irregular shape of the marginal tax profile is due to the 1991 tax-reform when the income tax-rate was considerably reduced for high-income earners. To compensate other groups additional basic deductions were allowed in certain income brackets. The profile of the basic deduction is shown in Figure 2, where we can see that it was designed to reduce taxes for low-income households. Overall, the marginal tax-rate on incomes from SEK 8,700 to SEK 67,900 was the same as the local tax-rate. However, from SEK 68,000 to SEK 105,200, the deduction increase with income, and the marginal tax-rate was lower (at 30\% municipal tax-rate, the marginal tax-rate was $22.5 \%)$. For incomes from SEK 110,800 to SEK 203,700, the basic deduction was reduced as income increased, and the marginal tax-rate was higher than the municipal tax-rate.

\subsection{Means-tested welfare programs in Sweden}

The three means-tested welfare programs in Sweden are SA, Housing Allowance (HA), and Cost of Childcare (CC).

SA is supposed to be the ultimate safety net for people having temporary money problems. Individuals are not entitled to SA if they have money in a bank account or other assets, which means for example that unemployment benefits, national child allowance, sickness benefits, and various pensions, must be exhausted first. SA is supposed to provide "decent" living, and thus depends on household composition. Since 1998, when a uniform national benefit-level replaced the previous variations in the benefit-levels, there have been no regional differences in SA benefits. To be entitled to SA, a household must have net income below the maximum benefit-level. 
There is then an implicit tax-rate of $100 \%$ on SA as household income increases. Table 2 presents the rules for SA for a single parent household. A single mother with two children, ages 2 and 4, is entitled to $2,320+1,310+1,230+760+$ housing rent + CC less after tax earned income.

HA, which is mainly directed to families with children, is also determined by nationwide rules. ${ }^{5}$ The amount of HA a household is entitled to is determined by household income, rent, the number of children and the age of the parents.

Childcare payment schemes vary by municipality, household's income, and the number and ages of the children. $\mathrm{CC}$ is especially important in the household budget since it typically increases with hours of work. Typically, fees paid increase progressively with income. However, the recent "maxtaxa" reform implemented in 2002 reduced the $\mathrm{CC}$ by introducing an upper ceiling in childcare fees. For one child the monthly fee is now SEK 1,150 or $3 \%$ of household income; for the second child it is SEK 767 or $2 \%$ of household income; and for the third child, it is SEK 383, or 1 $\%$. This reform reduces some households' expenditure for childcare dramatically, but the effect on single mothers was less dramatic, since this low -income group already had relatively low fees.

Figure 3 illustrates how SA, HA, and CC benefit-levels varied in 1999 with net income for a single mother with two children, ages 2 and 4 . SA benefit was reduced $100 \%$ with income. HA was constant for income below SEK 117,000, then reduced by $20.6 \%$ of income until SEK 296,000 or more. There is no difference between the

\footnotetext{
${ }^{5}$ However, single persons less than 29 years old and without children are entitled to apply for the allowance.
} 
new and old childcare payment schemes up to an income of SEK 119,000. For higher incomes, the new childcare payment scheme charges a lower fee. At an income of SEK 300,000, the saving is about SEK 6,000 per year.

To summarize, the main source of non-convexity in budget-sets is the generous but sharply declining welfare system designed to equalize income distribution.

Progressive income taxes also produces non-conve xities, but not as large as those produced by the welfare systems.

\section{The proposed tax, benefit and childcare reform}

As in many other countries, there is anxiety in Sweden about the high marginal taxrates for low-income households implied by an increase in working hours. This effect is due to a relatively high-income tax-rate on low-incomes, combined with a high implied-tax on welfare benefits. In order to reduce work-disincentive effects from the current tax and benefit system, we propose the following reform:

- increase the basic tax deductions on earned income SEK 8,700 to SEK 36,400 (one "base-amount");

- reduce SA benefit-levels $10 \%$;

- "maxtaxa" reform that reduce childcare fee;

In line with U.K. Working Families Tax Credit (WFTC) and the Earned Income Tax Credit (EITC) in the U.S., we include an implicit work requirement. Though each proposed change is general, the overall package is intended to target single mothers specifically.

As an illustration of the possible incentive effects of this reform, we calculated the 
net-replacement rates for the unemployed mothers in our sample. Before the reform, the net replacement rate for going to part-time work was $91 \%$, while full-time work was $79 \%$; after the reform; these rates were $82 \%$ and $68 \%$. The major reason for the reduced disincentive effect is the increase in the basic deduction, shown in Figure 2. Our proposal would shift the whole curve up. At about SEK 100,000 income the deduction would reach a maximum of about SEK 45,000. Figure 1 show the effect on average tax-rates: lower for all households, but much lower for low-income families.

It can be instructive to compare the basic deduction with a tax credit. There is a conceptual difference in that a tax credit is a subsidy paid to the household. Thus in the U.S. a single mother with two children who earned less than \$8,890 in 1996 received a $40 \%$ EITC on dollars earned (see Meyer and Rosenbaum 2000). Because the credit was refundable and a mother of two with those earnings was not subject to federal income tax due to the standard deduction, she would have received a check from the IRS for the credit amount. In contrast, under our proposal, a single Swedish mother with a low-income, say SEK 100,000, would deduct about SEK 45,000 from her earnings and then she would pay income tax on the remaining amount.

Even if the U.S. and U.K. tax credit schedules depend on family characteristics (and regions), it is thus still possible to compare EITC and WFTC to the Swedish basic deduction. The EITC is similar to the basic deduction in that it starts at zero and extends to relatively high earnings; in 1996 the maximum credit for a single mother with two children was $\$ 3,556$, based on earnings from $\$ 8,890$ to $\$ 11,610$. Given a purchasing power adjusted exchange rate in 1996 of $\$ 1=$ SEK 9.68, these levels are similar to the proposed basic deduction. The profile of the U.K. WFTC is rather 
different. The credit starts at a maximum amount but at a much higher level of earnings (16 hours of work per week) and then decreases gra dually to zero when earnings reach $£ 17,481$.

The use of credits versus deductions has political implications. Duncan and Giles (1998) discuss the change from the family credit to the WFTC in U.K.. One motive was presentational: "In particular, increasing the generosity of the support could then be presented as a tax cut rather than an increase in Government spending". However, in terms of reducing disincentive effects, deductions and credits are essentially the same, what matters is the marginal effect.

\section{The economic model and empirical specification}

The traditional way to model labor supply assumes that the decision-variable, hours of work, is continuous, but restrictive assumptions must be made in order to guarantee statistical coherency (see for instance the discussion in MaCurdy et al. 1990).

Moreover, an underlying assumption in traditional labor supply models is that the individual (or household) budget-set is convex. To estimate such a model, a number of important simplifications of the income tax and welfare systems must be made.

Following previous work by Van Soest (1995), Hoynes (1996), Keane and Moffitt (1998), and Blundell et al. (2000), we instead model labor supply as a discrete choice, which allows us to include more details regarding the budget-set. Specifically, we assume that each household can choose among the alternatives in the choice-set of income-leisure combinations $\left(C_{i}, L_{i}\right)$, where $i=1, \ldots, I$, and $L_{i}=T E-h_{i}$, with $T E$ denoting 
time-endowment, set to 4,000 hours per year. ${ }^{6}$ Thus, the choice-set for a household contains $I$ different hours of work combinations. In the empirical part of the paper we set $I=5^{7}$

The utility function is assumed to increase in disposable income, and to decrease with hours of work and with welfare participation. We thus assume that there is a negative side- effect, a non-monetary disutility associated with receiving SA. ${ }^{8}$

To allow for non-participation (following Moffitt 1983, Hoynes 1996, and Keane and Moffitt 1998), the disutility from welfare participation, $\mathrm{d}_{\mathrm{s}} \mathrm{A}$, is assumed to be separable. Thus this disutility is assumed to affect the decision to participate in welfare, but not decision to work conditional on receipt of welfare.

The econometric model we used follows the model used in Van Soest (1995) and Flood et al. (forthcoming). Preferences for disposable income and leisure are described by a direct translog utility-function:

$$
\begin{aligned}
\mathrm{U}\left(\mathrm{C}_{\mathrm{i}}, T E-h_{i}\right) & =\beta_{C} \log \left(\mathrm{C}_{\mathrm{1}}\right)+\beta_{\mathrm{L}} \log \left(T E-h_{i}\right)+\beta_{\mathrm{CC}}\left(\log \left(C_{i}\right)\right)^{2}+\beta_{\mathrm{LL}}\left(\log \left(T E-h_{i}\right)\right)^{2} \\
& +2 \beta_{\mathrm{CL}} \log \left(C_{i}\right) \log \left(T E-h_{i}\right)-\mathrm{fd}_{\mathrm{SA}}
\end{aligned}
$$

The household chooses disposable income, leisure, and welfare participation by maximizing the utility function (1) subject to the budget-constraint

$$
C=\mathrm{Wh}+\mathrm{Y}+\mathrm{V}-\mathrm{t}(\mathrm{I})+B_{S A}+B_{H A}-B_{C C}
$$

where $\mathrm{C}$ is income after taxes; $\mathrm{W}$ is the gross -wage per hour; $\mathrm{h}$ is hours of market

\footnotetext{
${ }^{6}$ TE can also be regarded as a parameter that can be estimated together with all other parameters.

${ }^{7}$ We set $\mathrm{h}_{1}=0, \mathrm{~h}_{2}=750, \mathrm{~h}_{3}=1,500, \mathrm{~h}_{4}=2,250, \mathrm{~h}_{5}=3,000$.

${ }^{8}$ What may be interpreted as "stigma" or disutility from welfare participation could also result from the inability of the econometrician to measure true welfare-eligibility. Imperfect information on the part of the household regarding benefit eligibility is also included in this non-monetary cost.
} 
work per year; and $\mathrm{Y}$ and $\mathrm{V}$ are respectively taxable and non-taxable unearned income per year. Income taxes are determined by the tax function $t(\cdot)$, where the argument is taxable income. Finally, the amount of household-specific means-tested subsidies is given by $B_{S A}$ (for SA), $B_{H A}$ (for HA) and $B_{C C}$ (for CC). These means tested subsidies depend on family income.

The inclusion of disutility from welfare participation implies that a family faces $2^{*} I$ work and welfare possibilities, though some might be infeasible if household-income from work were sufficiently high to render the household ineligible for SA. Solving the optimization problem requires evaluating the utility function (1) for each possible work and welfare combination and choosing the one that yields the highest utility.

Fixed Costs of working (FC) can be incorporated in the utility function by replacing the argument $\log \left(\mathrm{C}_{\mathrm{i}}\right)$ for employed individuals with $\log \left(\mathrm{C}_{\mathrm{i}}\right)-\log \left(\mathrm{FC}_{\mathrm{i}}\right)$. Since utility increases with income, positive fixed costs reduce the utility of the employed but do not affect the utility of the unemployed. The level of fixed costs may depend on the geographical region. Following Van Soest and Das (2001), we modeled the costs loglinearly as: $\log \left(F C_{i}\right)=\gamma_{1} z_{1}+\gamma_{2} z_{2}+\ldots+\gamma_{k} z_{k}$.

The flexible discrete specification in Equation (1) does not automatically fulfill the quasi-concavity conditions, but these conditions can be tested ex post, in contrast with a continuous model in which quasi-concavity has to be imposed a priori in order to guarantee coherency.

In order to empirically implement the model, we needed to specify the nature of 
heterogeneity in household preferences and the stochastic disturbances. Heterogeneity in preferences for leisure, disposable income, and welfare participation was introduced as

$$
\begin{aligned}
& \beta_{L}=\sum_{k=1}^{K} \beta_{L, k} x_{k}+\theta_{L} \\
& \beta_{C}=\sum_{k=1}^{K} \beta_{C, k} x_{k}+\theta_{C} \\
& \phi_{S A}=\sum_{j=1}^{J} \beta_{S A, k} w_{k}+\theta_{S A}
\end{aligned}
$$

where the elements of the vectors $x$ and $w$ are observed individual and family characteristics; $K$ and $J$, respectively, denote the dimensions of the vectors $x$ and $w$; while the $\theta$ 's represent unobserved variables that affect preferences for leisure, disposable income, and welfare participation.

It is reasonable to assume that an important source of population heterogeneity in terms of preferences is unobserved. In order to take this into account, we formulated a finite mixture model, which allows for unobserved heterogeneity in a very flexible way, without imposing a parametric structure. This idea for incorporating unobserved heterogeneity originates from Heckman and Singer (1984); and there are a number of applications to duration data (Ham and Lalonde, 1996), to count data (Deb and Trivedi, 1997), and to labor supply (Hoynes, 1996). Heckman and Singer (1984) also show that estimation of a finite mixture model might provide a good discrete approximation even if the underlying distribution is continuous. To be specific, we assumed that there exist $M$ different sets of $\left\{\theta_{\mathrm{L}}, \theta_{\mathrm{C}}, \theta_{\mathrm{SA}}\right\}$ that determine a family's preferences, each observed with probability $\pi_{\mathrm{m}}$ (where $\pi_{\mathrm{m}}>0$ and $\Sigma \pi_{\mathrm{m}}=1, m=1, \ldots$, $M)$. This specification allows for arbitrary correlations between work effort and 
preference for welfare participation.

To make the model estimable, additional random disturbances were added to the utilities of all choice-possibilities.

$$
U_{i, q}=U\left(C_{i}, T E-h_{i}\right)+\varepsilon_{i, q}
$$

where $i(=1, \ldots, I)$ represents the choice of labor supply; $q(=1,2)$ represents welfare participation or not; $U_{i, q}$ denotes the utility of choice $(i, q)$. We assumed that $\varepsilon_{i, q}$ follows a type I extreme-value distribution with cumulative density $\operatorname{Pr}\left(\varepsilon_{\mathrm{i}, q}<\varepsilon\right)=\exp (-\exp (-\varepsilon))$. The error term $\varepsilon_{i, q}$ can be interpreted as an optimization error; thus it has a different interpretation compared to the $\theta$ 's introduced above, which represent unobserved preferences for leisure, disposable income, and welfare participation.

Given the distributional assumptions of the stochastic terms in the utility function, the contribution to the likelihood function for a given household is

$$
\begin{aligned}
& l=\sum_{m=1}^{M} \pi_{m}\left\{\sum_{q=1}^{2} \sum_{i=1}^{I}(p \mid \Theta)_{i, q}\right\} \delta_{i, q} \\
& \text { where } \\
& (p \mid \Theta)_{i, q}=\frac{\exp \left(U_{i, q} \mid \Theta\right)}{\sum_{s=1}^{2} \sum_{t=1}^{I} \exp \left(U_{t, s} \mid \Theta\right)}
\end{aligned}
$$

$\mathrm{T}=\left\{\theta_{\mathrm{L}}, \theta_{\mathrm{C}}, \theta_{\mathrm{SA}}\right\}$ and $\delta_{i, q}$ is an indicator for the observed state for each household. The last expression (6) simply denotes the probability that the utility in state $(i, q)$ is the highest amongst all possible work and welfare combinations, conditional on unobserved preferences. 


\section{Description of the data}

The data was taken from the Swedish register-based LINDA. LINDA consists of a large panel of individuals and their household members, representative of the population from 1968 to 2001. The first wave took place in 1994 when 300,000 individuals were drawn (about $3 \%$ of the Swedish population). These individuals were followed back to 1968 but also forward, in order to create a panel, which is updated annually. Each wave is cross sectional representative of the population, since new individuals replace individuals who leave (divorce, dies, or emigrate).

The sample used in this study comes from the 1999 wave of LINDA. We included single mothers older than 17 and younger than 56 with 1 to 5 children, the youngest being 12 year or younger. We excluded single mothers who were students, retired, self-employed, or had taxable wealth. ${ }^{9}$ We ended up with a sample of 3,704 single mothers who, apart from their labor income, might have been eligible for SA.

Information on incomes, wages, transfers, taxes, wealth, and educational attainments was obtained from various government registers, where information on capital gains or losses was obtained from income tax returns.

The definition of a household is a problem in most administrative data, and LINDA is no exception. For economic analysis the most natural would be to define "household" as an economic unit, but in LINDA it is defined according to tax status. There is then a possibility that the number of single mothers may be overestimated if, for instance,

\footnotetext{
${ }^{9}$ Only wealth above SEK 900,000 is subject to tax, and only a few households are affected by this selection.
} 
she is living together with a man without being married and without having common children. We have not tried to adjust for this, but according to alternative data sources ${ }^{10}$, which are survey-based and therefore use an economic definition, the differences are quite small. About $5 \%$ of all households can be classified as headed by single mothers.

Wage data was collected from the official statistics by Statistics Sweden, based on employers' reports. Employers report monthly earnings, expressed in full-time equivalents and giving the amount the individual would have earned if working fulltime. To obtain hourly wage rates, the monthly earnings are divided by 165 . Yearly hours of work, $\mathrm{h}$, is then defined as total labor earnings divided by the hourly wage rate. The hourly wage rate used here is quite different from that obtained by dividing observed earnings by observed hours, which has a tendency to include measurement errors. The data used here is not subject to the same problem.

As usual, a remaining problem is that wage rates are missing for unemployed individuals. We predicted missing wage rates by estimating a wage equation, using a standard Heckit-approach. The labor supply model was then estimated using these predicted wage rates for the unemployed and actual wage rates for the employed. The total income of a household consists of both earned and unearned income. Unearned incomes include any capital gains, the national child allowance, and any child-support payments. Unemployment benefits and other transfers that depend on labor supply were excluded from our measure of unearned income. We allowed the basic deduction that depends on income, as shown in Table 1, to vary with hours of

${ }^{10}$ The household income survey (1999), Statistics Sweden, and the household market and non-market activities survey, Flood et al. (1996). 
work. Other income-dependent deductions were excluded.

Unfortunately, there is no information in LINDA about housing rent or about how many households use municipal childcare. Therefore, the rent of housing was imputed using information from an alternative data source, the Swedish Household Income Survey 1999, also supplied by Statistics Sweden. In the imputation we used the method of minimum-distance, using age, number of children, earnings, place of residence, and citizenship as classification variables. The childcare fees could still be calculated since the rules are known. The budget-set has been constructed assuming that all mothers used municipal childcare.

In LINDA there is register-information on the number of months each household received SA (as well as the amount received), but not which months. ${ }^{11}$ Thus we were not able use monthly data in the analysis, but instead aggregated all information to an annual basis. A household is then defined as an SA-recipient if it received SA at least two months during the year. Most of the SA-households received benefits for a short period. Of all the SA-recipients, about $46 \%$ received it for three months or less, and about $34 \%$ for more than six months.

To generate net income for various combinations of hours of work and welfare, we use a microsimulation model (FASIT). ${ }^{12}$ FACIT contains very precise information on income tax rules, as well as eligibility-rules for a number of welfare programs, such as SA and HA. It also enabled us to calculate the childcare choice of hours of work and

\footnotetext{
${ }^{11}$ Having access to register-data on welfare participation is a great advantage compared to interviewdata, as there is no under-reporting of welfare participation in register-data.

12 FASIT was developed and is used by Statistics Sweden and the Swedish Ministry of Finance.
} 
welfare. Access to a simulation-model such as FASIT was essential for calculating accurate (net) household incomes, conditional on labor supply, because income tax rules and the various welfare benefit-levels are complicated functions of earned and unearned income. FASIT includes most of the municipalities and their fee-structures for childcare. For municipalities not included, other methods of imputation were used. We added an assumption to FACIT regarding the use of childcare given various hours of work possibilities.

The variables included in the $x, w$ and $z$ vectors (which determine observed heterogeneity in leisure, disposable income, welfare participation, and fixed costs of working) were: age; age squared; a dummy variable for the single mother being in the age cohort 18-29; two dummy variables describing the highest education level completed (primary school or high school); three dummy variables for the age of the youngest child; a dummy variable indicating if the single mother was born in Sweden; and finally, four dummy variables for residence Stockholm; Göteborg or Malmö; bigger cities; or the south central area.

Table 3 shows sample average, by SA status. Of the 3,704 households, 528 (14.3\%) received SA. Single mothers receiving SA were younger, less educated, and less likely to be born in Sweden. They worked less than those not receiving SA, and their wage rate was also lower. The average SA and HA, was SEK 36,490 and SEK 22,587 per year, respectively. Single mothers not participating in SA had a lower HA participation rate, $71 \%$ versus $97 \%$ and less average HA benefits, SEK 11,858. 


\section{Results}

\subsection{Structural estimates}

The estimated parameters of the structural model associated with observed heterogeneity are presented in Table 4. Before discussing the implications of these estimates, it is worthwhile noting that the utility function evaluated at these estimates and at observed hours of work and disposable income fulfills the conditions for quasiconcavity for virtually all-single mother households (the condition was rejected for only 52 household or $1.4 \%$ ). Since there is a fair amount of variation in both hours of work and disposable income, this suggests that the utility function is concave over a large region. Given that the estimated utility function satisfies the theoretical requirements, we used it for predictions and simulations.

All parameters reflecting observed heterogeneity in preferences for leisure (column one) have a statistically significant effect. As expected, there is a strong and positive effect of younger children on the preference for leisure. A lower level of education also has a strong positive effect. Age has a negative effect, while age squared is positive as does living in Stockholm. Fixed costs of working (column 3) depend on the region of residence. The fixed cost parameters are jointly significant and are positive for all individuals in the sample. The estimated intercept indicates that the costs increase the preference for leisure and that residence in Stockholm; Göteborg or Malmö; bigger cities; or the south central area have higher fixed cost compared to residence living in the northern region of Sweden. The last column in Table 4 refers to the disutility associated with SA participation. A positive coefficient implies that disutility increases in that variable, since $\phi_{S A}$ enters negatively in the utility function. 
The estimates suggest that the disutility of SA participation is higher among Swedish born households. Mothers who are young, have low education, and have young children, have lower disutility of SA participation.

Estimates of the distribution of the unobserved heterogeneity components are shown in Table 5. We report estimates based on four support points $(M=4)$ and used Akaike information criteria to compare models with different support points.

To illustrate the variation due to unobserved heterogeneity, we obtained type-specific predictions of hours of work and participation in SA. That is, we first assumed that every household in the sample has the unobserved preference-structure of type-one families, and predicted outcomes based on this. This was repeated for all four types, and the results are shown in Table 6. Type-one households, which comprise about 11 $\%$ of the sample, show a low preference for work but also a strong disutility from SA participation, indicated by the zero predicted participation rate. Type-two households show a mild preference for work and high-predicted SA participation (72\%). Types three and four households show progressively higher preference for work. Type-three households show a mild preference for SA participation, while type-four shows a zero SA participation rate.

The specification used for the distribution of unobserved heterogeneity allows for unrestricted correlations with unobserved elements of work effort and welfare participation. For single mothers, the empirical correlation coefficient between work effort and participation in SA is -0.14. Negative correlations between work effort and welfare participation were also found by Hoynes (1996) and Flood et al. 
(forthcoming), and suggest self-selection into welfare programs.

A well-known problem of labor supply models is their poor ability to fit the observed distribution of hours of work. One way to improve the fit of these models is to control for unobserved fixed costs of work (see for example Kapteyn et al. 1990 and Van Soest 1995). Alternatively, we specified a flexible model with respect to unobserved heterogeneity, which might represent unobserved fixed costs of work, as well as unobserved preferences for leisure. As can be seen in Table 7, the observed distribution of hours is quite similar to the predicted distribution.

The effects of wage changes were assessed using simulations. Specifically, wages were increased by $1 \%$ for everyone in the sample and the resulting changes in predicted working hours were calculated. Everything else constant, the simulated result of a $1 \%$ wage increase for single mothers, is an average increase in hours of $0.62 \%$. Table 8 presents previous results of uncompensated labor supply elasticities for single mothers. There is a great deal of variation, from 0.13 to 1.82 . Our result are somewhere in the middle.

\subsection{Simulation of the proposed tax and benefit reform}

Table 9 presents the results from simulation of the proposed tax and benefit reform. Average hours of work are predicted to increase by $5 \%$. Disposable income increases by almost $7 \%$ and employment to increase from $78 \%$ to $82 \%$, while welfare participation drops from $12 \%$ to $7 \%$, and average SA received is cut in half. Finally, due to the "maxtaxa" reform, childcare fees drop by more than $30 \%$. Overall, the dramatic tax cut, together with increased working hours and reduced childcare fees, results in an increase of disposable income by SEK 10,000 per year. The reform 
brings welfare-gains for almost everyone in the sample; EV is $6.6 \%$ of disposable income before the policy reform.

Table 9 also shows the distributional effects of the reform: a dramatic increase in working hours for low-income households (38\%), and an increase in first quartile disposable income by $11 \%$. SA participation decreased considerably, from $18 \%$ to $10 \%$, about the same relative decline as for the whole sample. The reason is that SA is to such a large degree an in-work support; even some mothers in the upper quartile receive SA. However, the amounts received vary with income; for the lower quartile the drop is SEK 4,817, compared to SEK 2,549 for the upper quartile.

The "maxtaxa" reform of childcare fees disproportionably benefited the upper quartile, for which the drop is $33 \%$, compared to $25 \%$ for the median and only $6 \%$ for the lower quartile. This is because low-income mothers already paid low fees, since most fees before the reform were based on earnings. Furthermore, mothers who started to work as a result of the reform now pay fees that they did not do before. Since many of those new workers are in first quartile, the result is that low-income households do not gain much from the "maxtaxa" reform.

Even if the childcare reform does not benefit low-income households very much the overall reform does. EV is $10 \%$ of disposable income before the policy reform, for the lower quartile, compared to about $8 \%$ for the median and $5 \%$ for the upper quartile.

\subsection{The cost of the proposed tax and benefit reform}

In this section we focus on the effects on government tax revenues and expenditures. 
Total taxes and benefits were calculated for each household before and after the reform, and then the weighted population-sums were calculated. Revenues were calculated as the sum of income and payroll taxes, plus Value-Added Taxes (VAT) and also the childcare fees paid by household. The cost of the reform was calculated as the amount of HA and SA received by the household.

Payroll tax was calculated as $33.06 \%$ of the wage rate net of payroll taxes. VAT was calculated as $17.6 \%$ on $90 \%$ of disposable income. ${ }^{13}$

Table 10 summarizes the total effects of the reform with and without labor supply adjustments. A static comparison before and after the reform shows a deficit SEK 9,186 million - SEK 8,477 million = SEK 709 million. The major impact is the drop in income tax revenues, from SEK 4,586 million to SEK 3,765 million. Revenues from childcare fees drop SEK 626 million to SEK 422 million, though VAT goes up. Finally, the $10 \%$ decrease in SA benefits together with the tax-reduction and decreased level of SA participation reduces the cost of SA from SEK 825 million to SEK 626 million. However, allowing for labor supply adjustments, the drop in income taxes is smaller since earnings have increased due to an increase in working hours, and payroll taxes have increased as well. The childcare fees paid by households are below the level before the reform, due to "maxtaxa", but higher then the static results, since working hours have increased, and more childcare are utilized. ${ }^{14}$ There is only a minor effect on HA, because most single mothers would be eligible even with increased income. Even high-income mothers may receive HA (see Figure

\footnotetext{
13 Governmental proposition 2002/03:1, page 137.

${ }^{14} \mathrm{It}$ is important to remember that this might result in higher government cost for providing childcare.
} 
3). An important and major effect is the further dramatic reduction in cost of SA, to SEK 400 million, because of increased earnings due to more hours worked. Finally, there is a further slight rise in VAT, paid on increased disposable income spent.

To summarize, due to dynamic effects, the reform was almost revenue-neutral. Government revenues from income taxes and childcare fees dropped but this were compensated for by increased revenues from payroll taxes and VAT, as well as reduced cost for $\mathrm{SA}$.

\subsection{Robustness}

This subsection examines the robustness of our results to different model assumptions as well as to a different definition of SA participation. Regarding alternative model specifications, we considered a model with no unobserved heterogeneity; a model with three support points; and three models where we have three, seven, and nine working hours classes, respectively. To assess the effects of wage changes on labor supply, we again increased wages by $1 \%$ and calculated the resulting changes in predicted working hours. Depending on model specification, a $1 \%$ wage increase was associated with increased hours of work ranging from $0.50 \%$ to $0.69 \%$, compared to $0.62 \%$ in our preferred specification.

We then re-estimated the main model using a different definition of SA participation. Previously a household was recorded as SA participating if it received SA for more than one month during the year. To verify that our results were not driven by our assignment rule for SA participation, we now used the definition that households are recorded as SA participating only if they received SA for more than three months during the year. The labor supply effects from wage changes using this new definition 
of SA were similar to the ones reported above, with an increase in hours of work by $0.63 \%$.

Overall, we found that the results and modelimplications were quite robust towards changes both in different working classes and the specification of unobserved heterogeneity.

\section{Conclusions}

The main purpose of this study was to evaluate a proposed tax and benefit reform, targeted at single mothers, designed to increase labor-market participation as well as working hours. The reform includes reducing income taxes, and the level of SA, as well as childcare fees.

We used a sample of Swedish single mother households with detailed and unique information on incomes and benefits and estimated a structural labor supply model, with labor supply and welfare participation jointly determined. We allowed for unobserved heterogeneity and also for these effects to be correlated across alternatives. One distinctive feature of the study is the detailed construction of the budgetsets using a modified tax-benefit program designed at Statistics Sweden and the Swedish Ministry of Finance.

As an illustration of the possible incentive effects of this reform, we calculated the net-replacement rates for the non-working females in our sample. Before the reform, the net replacement-rate for going to part-time work was $91 \%$, while full-time work was $79 \%$; after the reform; these rates were $82 \%$ and $68 \%$. 
In simulated results, $6 \%$ of single mothers change their working hours in response to the policy change and working hours increased $5 \%$ on average, while disposable income increased almost $7 \%$, SA participation decreases by almost $41 \%$, and the cost of SA decreased by $50 \%$.

There were welfare-gains for virtually everyone in the sample. The average EV for the whole sample was almost $7 \%$ of before-reform disposable income with the lower quartile gaining almost $10 \%$.

Due to dynamic effects, the reform was almost revenue -neutral. Government revenues from income taxes and childcare fees dropped but this were compensated for by increased revenues from payroll taxes and VAT, as well as reduced cost for SA.

The reform is not Pareto-optimal. The losers are those mothers who did not work either before or after the reform. Given that they were eligible for SA they would be directly affected by the $10 \%$ decrease in benefit-level.

How can we justify a reform that "hurts" the poorest? Less than $5 \%$ of mothers belong to this group. Not very surprisingly these are mothers with attributes that produced a low predicted probability of work, such as young immigrant mothers with low education and young children. This suggests that other reforms or programs are needed apart from changes in the tax and benefit systems. Labor-market training programs targeted at these mothers as well as educational programs aimed at increasing labor-market participation, are a necessary complement to a reform that includes a reduction in benefit-levels. The socalled "Storstadssatsningen" is one 
example of such a program, targeted at large-city areas with a large proportion of immigrant households. Similar programs are also quite frequent in the U.S., and since participation in them has been mandatory for welfare recipients, they can be considered as integral part of the welfare system. To include such programs in the proposed reform would increase the possibility of reducing economic disincentives. SA traditionally has been considered as a last resort, the last safety net. Our overall ambition must be to reduce the number of people dependent on welfare, and especially those who are long-term dependent. This can only be achieved by economic incentives accompanied by well-targeted training and educational programs.

To conclude, our findings suggest that the goal of reducing SA by half can be met via a reform that is easy to implement, benefits low-income households, and would at the same time be more or less revenue neutral. 


\section{Acknowledgements}

We would like to thank Thomas MaCurdy and Alan Duncan, as well as seminar participants at Göteborg University, for helpful comments and suggestions. Financial support from the Jan Wallander and Tom Hedelius Foundation for Research in Economics is also gratefully acknowledged.

\section{References}

Andrén, T. 2003. The choice of paid childcare, welfare, and labor supply of single mothers. Labour Economics 10, 133-147.

Blank, R. 2002. Evaluating welfare reform in the United States. Journal of Economic Literature 40, 1105-1166.

Blundell, R., Duncan, A., Meghir C., 1992. Taxation in empirical labour supply models: Lone mothers in the U.K. Economic Journal 102, 265-278.

Blundell, R., Duncan A., McCrae J., Meghir C. 2000. Evaluating in-work benefit reform: The Working families tax credit in the U.K. Working paper, University of Nottingham: http://www.nottingham.ac.uk/ lezad/work/.

Blundell, R., Hoynes, H. 2003. Has "in-work" benefit reform helped the labour market? In: Card, D., Blundell, R., Freeman, R.B. (Eds), Seeking a premiere economy: the economic effects of British economic reforms, 1980-2000. Forthcoming from The University of Chicago Press, http://www.nber.org/books/bcf/blundell-hoynes2-3-03.pdf 
Blundell, R., MaCurdy, T. 1999. Labor supply: A review of alternative approaches. In: Ashenfelter, O., Card, D. (Eds), Handbook of Labor Economics, Vol. 3, Elsevier Science Press, New York, pp. 1559-1694.

Deb, P., Trivedi, P. K. 1997. Demand for medical care by the elderly: A finite mixture approach. Journal of Applied Econometrics 12, 313-336.

Duncan, A., Giles, C. 1998. The labour market impact of the working families tax credit in the U.K.. Working paper, University of Nottingham:

http://www.nottingham.ac.uk/ lezad/work/.

Eklind, B., Eriksson, I., Holmberg, C., Hussenius, J., Lindeborg, K., Lindholm, L. E. 1997. Lönar sig arbete? ESO, DS 1997:73.

Flood, L., Hansen, J., Wahlberg, R. forthcoming. Household labor supply and welfare participation in Sweden. Journal of Human Resources.

Flood, L., Klevmarken, N.A, Olovsson, P. 1996. Household market and nonmarket activities (HUS), Volumes IV-VI, Department of Economics, Uppsala University, Uppsala.

Fraker, T., Moffitt, R. 1988. The effect of food stamps on labor supply: A bivariate selection model. Journal of Public Economics 35, 25-56.

Governmental proposition 2002/03:1. 
Graversen, E. K. 1996. Male and female labour supply in Denmark. Working Paper 96-15, Aarhus: Center for Labour Market and Social Research.

Ham, J., Lalonde, R. 1996. The effects of sample selection and initial conditions in duration models: Evidence from experimental data on training. Econometrica 64, 175205.

Heckman, J., Singer, B.L. 1984. A method for minimizing the distributional assumptions in econometric models for duration data. Econometrica 52, 271-320.

Hoynes, H. W. 1996. Welfare transfers in two-parent families: Labor supply and welfare participation under AFDC-UP. Econometrica 64, 295-332.

Kapteyn, A., Kooreman, P., Van Soest, A. 1990. Quantity rationing and concavity in a flexible household labor supply model. Review of Economics and Statistics 70, 55-62.

Keane, M., Moffitt, R. 1998. A structural model of multiple welfare program participation and labor supply. International Economic Review 39, 553-589.

Levy, F. 1979. The labor supply of female household heads, or AFDC work incentives don't work too well. Journal of Human Resources 14, 76-97.

MaCurdy, T., Green, D., Paarsch, H. 1990. Assessing empirical approaches for analyzing taxes and labor supply. Journal of Human Resources 25, 415-490. 
Meyer, B.D., Rosenbaum, D.T. 2000. Making single mothers work: Recent tax and welfare policy and its effects. National Tax Journal 53, 1027-1062.

Meyer, B.D., Rosenbaum, D.T. 2001. Welfare, the earned income tax credit, and the labor supply of single mothers. Quarterly Journal of Economics 116, 1063-1114.

Moffitt, R. 1983. An economic model of welfare stigma. American Economic Review 73, 1023-1035.

Moffitt, R. 1986. Work incentives in the AFDC System: An analysis of the 1981 reforms. American Economic Review 76, 219-223.

Moffitt, R. 1992. Incentive effects of the U.S. welfare system: A review. Journal of Economic Literature 30, 1-61.

Preston, I., Walker, I. 1999. Welfare measurement in labour supply models with nonlinear budget constraints. Journal of Population Economics 12, 343-61.

The Swedish national health and welfare board 2002. Ekonomiskt bistånd 2001, Socialtjänsten 2002:6.

Van Soest, A. 1995. Structural models of family labor supply. Journal of Human Resources 30, 63-88. 
Van Soest, A., Das, M. 2001. Family labor supply and proposed tax reforms in the Netherlands. De Economist 149, 191-218. 
Table 1

The Swedish income tax system in 1999

\begin{tabular}{ccc} 
Income Levels (SEK) & Basic Deduction (SEK) & Marginal Tax-rate \\
\hline $100-8,600$ & All Income & $0 \%$ \\
$8,700-67,900$ & 8,700 & $30 \%$ \\
$68,000-105,200$ & $8,700+0.25 *$ (Income- 68,000$)$ & $22.5 \%$ \\
$105,300-110,700$ & 18,100 & $30 \%$ \\
$110,800-203,700$ & $18,100-0.1 *($ Income-110, 800$)$ & $33 \%$ \\
$203,800-219,300$ & 8,700 & $30 \%$ \\
$219,400-360,000$ & 8,700 & $50 \%$ \\
$360,100-$ & 8,700 & $55 \%$ \\
\hline
\end{tabular}

Note: The marginal tax-rate is calculated assuming a municipal tax-rate of $30 \%$.

Table 2

SA for single parents in Sweden (per month)

Single individual SA: SEK 2,320

+Child component Child's Age:

$\begin{array}{lllllll}0 & 1-2 & 3 & 46 & 7-10 & 11-14 & 15-18\end{array}$

$\begin{array}{llllllll}\text { SEK } & 1,100 & 1,310 & 990 & 1,230 & 1,530 & 1,830 & 2,070\end{array}$

+Common component Number of household members

$\begin{array}{lllllll}1 & 2 & 3 & 4 & 5 & 6 & 7\end{array}$

$\begin{array}{llllllll}\text { SEK } & 580 & 670 & 760 & 820 & 910 & 960 & 1,020\end{array}$

Source: Swedish national health and welfare board. 
Table 3

Sample averages by welfare status $(\mathrm{N}=3,704)$

\begin{tabular}{|c|c|c|c|c|}
\hline \multirow[b]{2}{*}{ Variables: } & \multicolumn{2}{|c|}{ Welfare } & \multicolumn{2}{|c|}{ No welfare } \\
\hline & Mean & SD & Mean & SD \\
\hline Welfare / no welfare & \multicolumn{2}{|c|}{$14.3 \%$} & \multicolumn{2}{|c|}{$85.7 \%$} \\
\hline Age & 33 & 7 & 37 & 6 \\
\hline \multicolumn{5}{|l|}{ Education (highest) } \\
\hline - Primary school (1=Yes) & 0.51 & 0.50 & 0.25 & 0.43 \\
\hline - High school (1=Yes) & 0.46 & 0.50 & 0.65 & 0.48 \\
\hline - University (1=Yes) & 0.03 & 0.18 & 0.10 & 0.30 \\
\hline Born in Sweden $(1=$ Yes $)$ & 0.67 & 0.47 & 0.87 & 0.34 \\
\hline \multicolumn{5}{|l|}{ Place of residence } \\
\hline - Stockholm (1=Yes) & 0.22 & 0.42 & 0.23 & 0.42 \\
\hline - Göteborg or Malmö (1=Yes) & 0.19 & 0.40 & 0.16 & 0.37 \\
\hline - Bigger cities $(1=$ Yes $)$ & 0.34 & 0.47 & 0.34 & 0.48 \\
\hline - Southern central (1=Yes) & 0.15 & 0.36 & 0.16 & 0.37 \\
\hline - Northern region ( $1=$ Yes $)$ & 0.10 & 0.30 & 0.10 & 0.30 \\
\hline Youngest child 1 year old (1=Yes) & 0.10 & 0.30 & 0.02 & 0.16 \\
\hline Youngest child 2-5 years old ( $1=$ Yes) & 0.42 & 0.49 & 0.27 & 0.44 \\
\hline Youngest child 6-9 years old ( $1=$ Yes) & 0.30 & 0.46 & 0.42 & 0.49 \\
\hline Youngest child $10-12$ years old $(1=$ Yes $)$ & 0.18 & 0.38 & 0.29 & 0.45 \\
\hline Working $(1=$ Yes $)$ & 0.42 & 0.49 & 0.85 & 0.36 \\
\hline Working-hours per year & 371 & 550 & 1,328 & 761 \\
\hline Wage/hour (SEK) & 88 & 14 & 101 & 23 \\
\hline SA per year (SEK) & 36,490 & 29,581 & - & - \\
\hline Receiving HA & 0.97 & 0.17 & 0.71 & 0.46 \\
\hline HA per year (SEK) & 22,587 & 10,969 & 11,858 & 11,561 \\
\hline Number of observations & & & & \\
\hline
\end{tabular}


Table 4

Estimates of a structural single mother labor supply model $(\mathrm{N}=3704)$

\begin{tabular}{|c|c|c|c|c|}
\hline Variables: & $\beta_{\mathrm{L}}$ & $\beta_{c}$ & FC & $\beta_{\text {SA }}$ \\
\hline Intercept & - & - & $1.69(0.08)$ & - \\
\hline Age & $-0.31(0.14)$ & $-0.12(0.13)$ & - & - \\
\hline $\mathrm{Age}^{2} / 100$ & $0.45(0.18)$ & $0.23(0.17)$ & - & - \\
\hline Age $18-29$ & - & - & - & $-1.17(0.37)$ \\
\hline \multicolumn{5}{|l|}{ Education (highest) } \\
\hline -Primary school & $1.27(0.42)$ & $-0.28(0.73)$ & - & $-1.75(0.32)$ \\
\hline -High school & $0.90(0.38)$ & $-0.30(0.69)$ & - & - \\
\hline Born in Sweden & - & - & - & $2.51(0.32)$ \\
\hline \multicolumn{5}{|l|}{ Place of residence } \\
\hline -Stockholm & $-0.88(0.40)$ & $-0.42(0.29)$ & $0.22(0.08)$ & - \\
\hline -Göteborg or Malmö & - & - & $0.12(0.05)$ & - \\
\hline -Bigger cities & - & - & $0.15(0.04)$ & - \\
\hline - Southern central & - & - & $0.07(0.05)$ & - \\
\hline Youngest child 1 year old & $5.73(0.96)$ & $-6.28(0.79)$ & & $-5.29(0.80)$ \\
\hline $\begin{array}{l}\text { Youngest child 2-5 years } \\
\text { old }\end{array}$ & $0.80(0.39)$ & $-1.41(0.50)$ & - & $-2.50(0.81)$ \\
\hline $\begin{array}{l}\text { Youngest child 6-9 years } \\
\text { old }\end{array}$ & $0.41(0.25)$ & $0.17(0.29)$ & - & - \\
\hline \multicolumn{5}{|l|}{ Utility parameters: } \\
\hline$\beta_{\mathbf{C C}}$ & \multicolumn{4}{|c|}{$-0.65(0.26)$} \\
\hline$\beta_{\mathbf{L L}}$ & \multicolumn{4}{|c|}{$-12.36(0.99)$} \\
\hline$\beta_{\mathbf{L C}}$ & \multicolumn{4}{|c|}{$-1.50(0.32)$} \\
\hline Log-likelihood value: & \multicolumn{4}{|c|}{$-5,682.30$} \\
\hline
\end{tabular}

Note: Standard errors in parentheses. 
Table 5

Estimates of the distribution of unobserved heterogeneity

\begin{tabular}{lcccc}
\hline Type $(\mathbf{m})$ & Type probabilities $\left(\pi_{m}\right)$ & Leisure $\left(\theta_{L}\right)$ & Income $\left(\theta_{C}\right)$ & SA $\left(\theta_{S A}\right)$ \\
\hline 1 & 0.11 & $41.2(4.7)$ & $1.1(2.2)$ & $12.6(0.1)$ \\
2 & 0.13 & $31.8(3.1)$ & $7.7(2.1)$ & $-1.6(0.6)$ \\
3 & 0.73 & $30.5(3.0)$ & $14.5(2.2)$ & $7.1(0.6)$ \\
4 & 0.03 & $6.8(4.6)$ & $-8.9(4.4)$ & $14.8(0.2)$ \\
\hline
\end{tabular}

Note: Standard errors in parentheses.

Table 6

Type specific predic tions of hours of work $(\mathrm{PH})$ and prediction of SA participation

$(\mathrm{SAP})$

\begin{tabular}{lccc}
\hline Type $(\mathbf{m}):$ & Type probabilities $\left(\pi_{m}\right)$ & PH & SAP \\
\hline 1 & 0.11 & 239 & 0 \\
2 & 0.13 & 675 & 0.72 \\
3 & 0.73 & 1,346 & 0.07 \\
4 & 0.03 & 2,340 & 0 \\
\hline
\end{tabular}

Table 7

Observed and Predicted Hours of WorkFrequencies

\begin{tabular}{ccc}
\hline Hour's category $\left(\mathbf{h}_{\mathbf{j}}\right):$ & Observed & Predicted \\
\hline$h=0$ & $21.14 \%$ & $21.76 \%$ \\
$0<h \leq 750$ & $11.61 \%$ & $10.96 \%$ \\
$750<h \leq 1500$ & $20.65 \%$ & $21.17 \%$ \\
$1500<h \leq 2250$ & $42.90 \%$ & $41.58 \%$ \\
$h>2250$ & $3.70 \%$ & $4.54 \%$ \\
\hline
\end{tabular}

Note: Predicted proportions were obtained using the estimates in Table 4. 
Table 8

Labor supply elasticities for single mothers

\begin{tabular}{llc}
\hline Study: & Data Source & Wage Elasticity \\
\hline Fraker and Moffitt (1988) & 1979 ISDP & 0.26 to 0.35 \\
Blundell et al. (1992) & 1981-86 FES & 0.16 \\
Graversen (1996) & 1990 DAP & 0.13 \\
Duncan and Giles (1998) & 1994-95 FRS & 0.52 \\
Keane and Moffitt (1998) & 1984 SIPP & 1.82 \\
Preston and Walker (1999) & 1990 FES & 0.29 \\
Andrén (2003) & 1997-98 HEK & 0.77 \\
\hline Note: ISDP=US Income Survey Development Program; FES = UK Family \\
\multicolumn{3}{l}{ Expenditure Survey; } \\
\multicolumn{3}{l}{ DAP=Danish Adult Population; FRS= UK Family Resources Survey; } \\
\multicolumn{2}{l}{ SIPP=US Survey of Income and Program Participation; HEK= Swedish Income } \\
Distribution Survey
\end{tabular}


Table 9

Results from a simulation of the proposed tax and benefit reform

\begin{tabular}{|c|c|c|c|c|}
\hline Variable. & $\begin{array}{c}\text { Whole } \\
\text { Sample }\end{array}$ & $\begin{array}{c}\text { Lower } \\
\text { quartile }\end{array}$ & Median & $\begin{array}{c}\text { Upper } \\
\text { quartile }\end{array}$ \\
\hline Working hours before reform & 1,189 & 377 & 738 & 1,795 \\
\hline Working hours after reform & 1,252 & 519 & 842 & 1,813 \\
\hline Working before reform & $78.2 \%$ & $48.9 \%$ & $65.0 \%$ & $94.7 \%$ \\
\hline Working after reform & $82.4 \%$ & $57.6 \%$ & $71.6 \%$ & $96.1 \%$ \\
\hline $\begin{array}{l}\text { Disposable income before reform } \\
\text { (SEK) }\end{array}$ & 139,737 & 86,064 & 107,681 & 191,232 \\
\hline $\begin{array}{l}\text { Disposable income after reform } \\
\text { (SEK) }\end{array}$ & 149,707 & 95,275 & 117,059 & 200,771 \\
\hline SA participation before reform & $11.9 \%$ & $17.6 \%$ & $15.4 \%$ & $6.6 \%$ \\
\hline SA participation after reform & $7.0 \%$ & $10.4 \%$ & $8.8 \%$ & $4.1 \%$ \\
\hline SA before reform (SEK) & 7,561 & 9,509 & 8,867 & 5,104 \\
\hline SA after reform (SEK) & 3,665 & 4,692 & 4,207 & 2,555 \\
\hline Childcare fees before reform (SEK) & 5,885 & 2,422 & 4,053 & 8,422 \\
\hline Childcare fees after reform (SEK) & 4,044 & 2,283 & 3,017 & 5,619 \\
\hline $\begin{array}{l}\text { Equivalent variation as percentage of } \\
\text { disposable income before reform }\end{array}$ & $6.6 \%$ & $9.8 \%$ & $8.4 \%$ & $5.0 \%$ \\
\hline
\end{tabular}

Note: Reported values for the whole sample refer to sample means. 
Table 10

Government revenues before and after the proposed reform (SEK million)

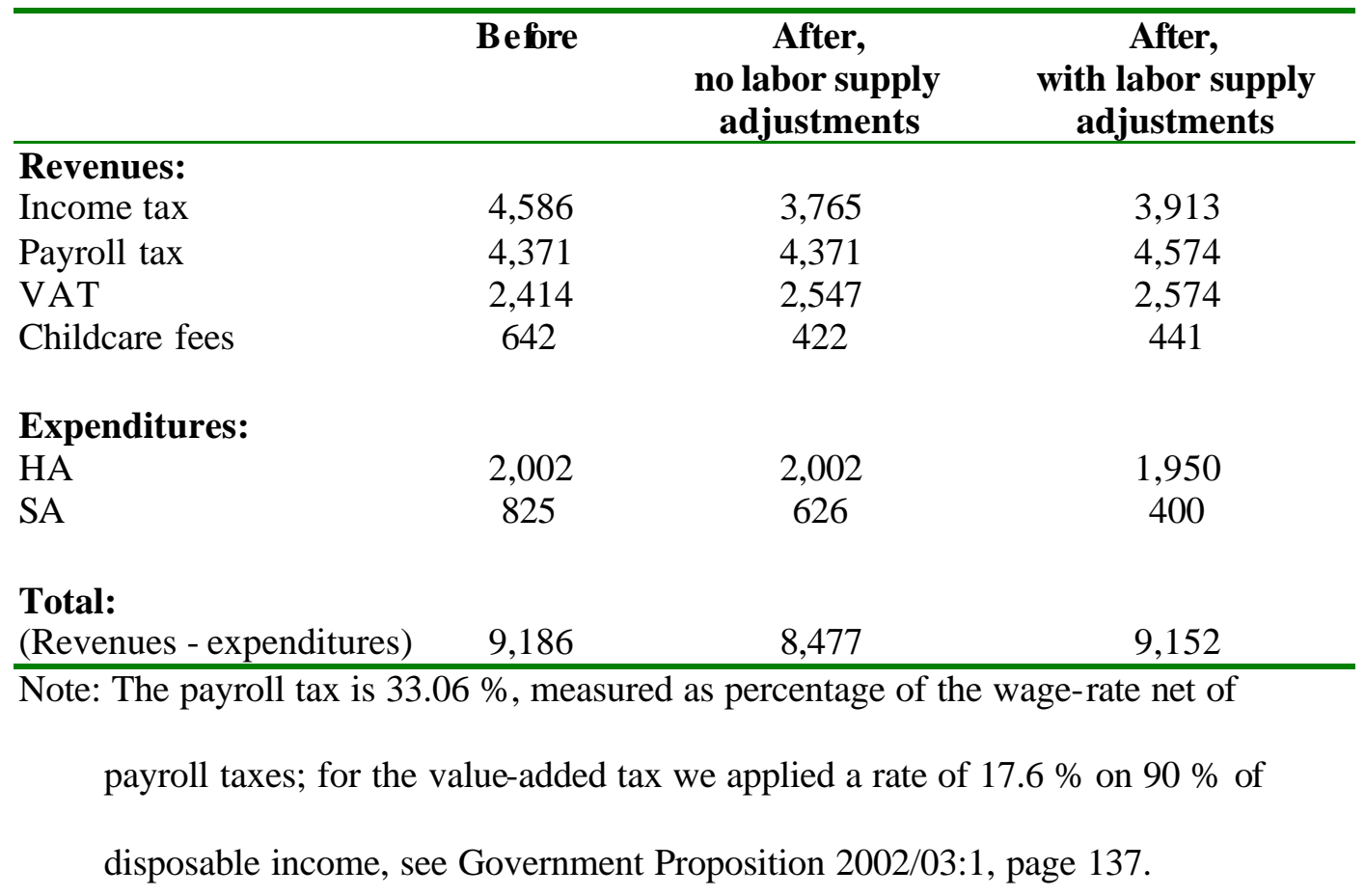




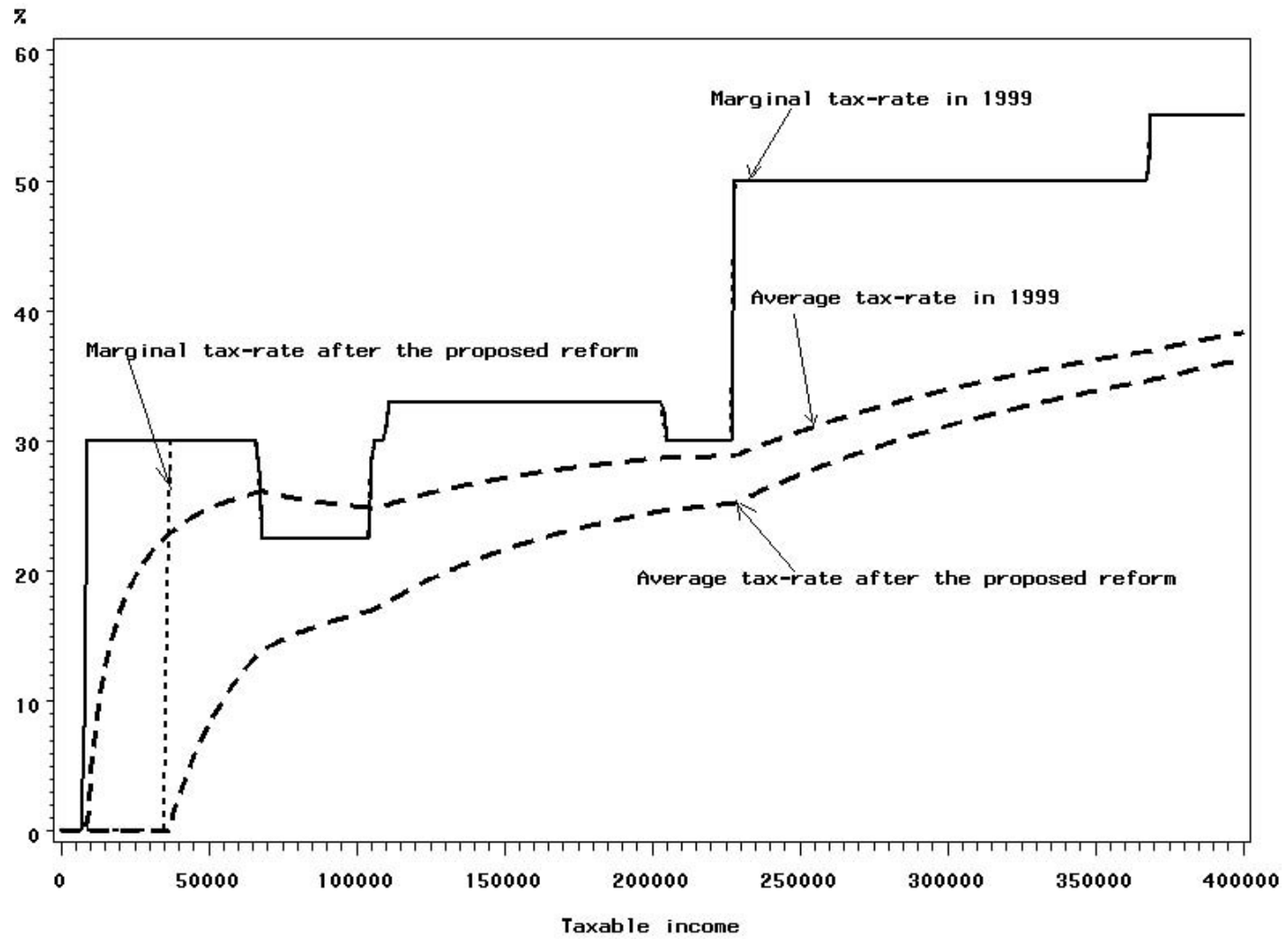

Figure 1. Marginal and average income tax-rate in 1999 and after the proposed reform (SEK). 


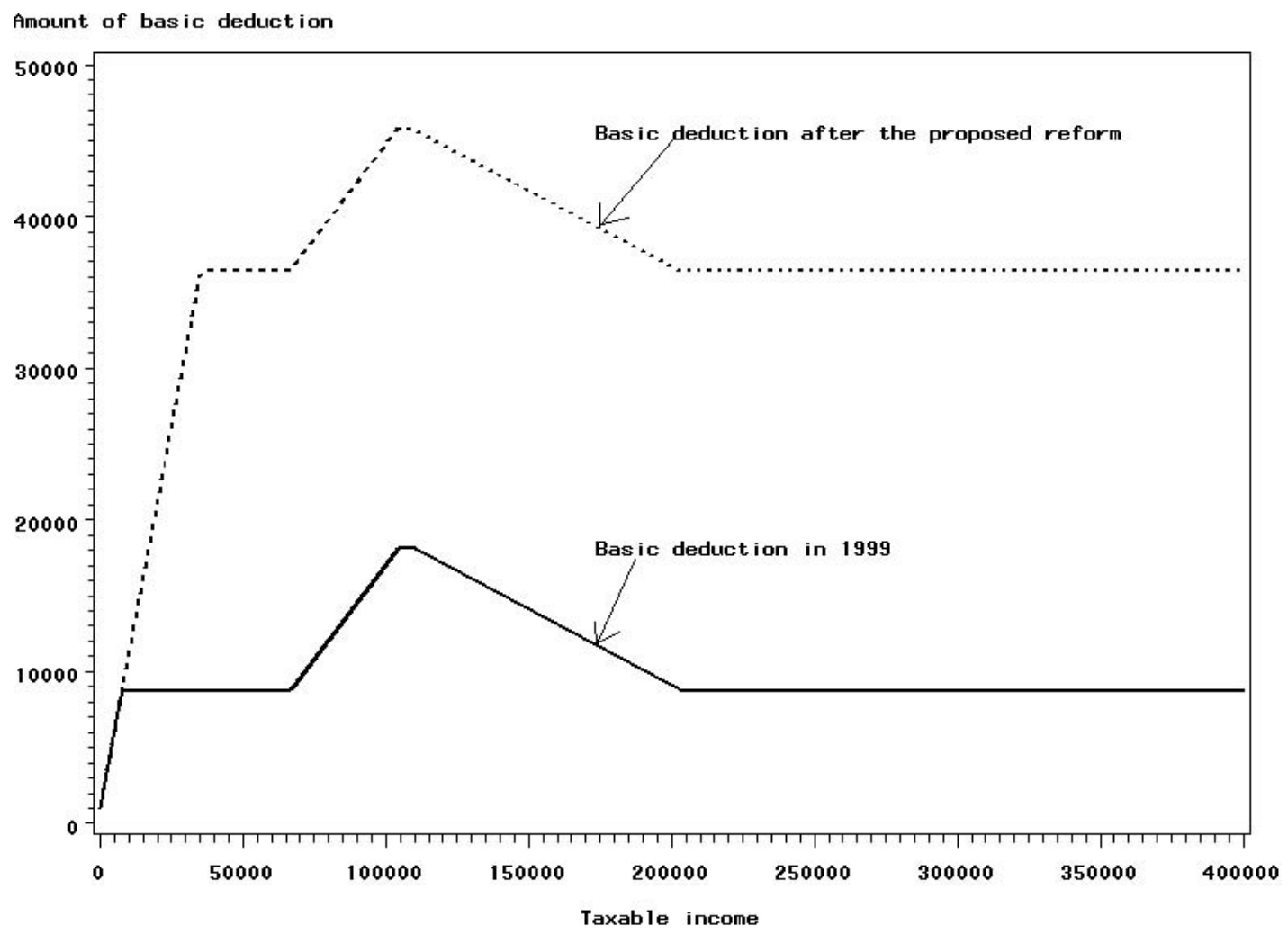

Figure 2. Basic deduction before and after the proposed reform (SEK). 
Amount of benefits

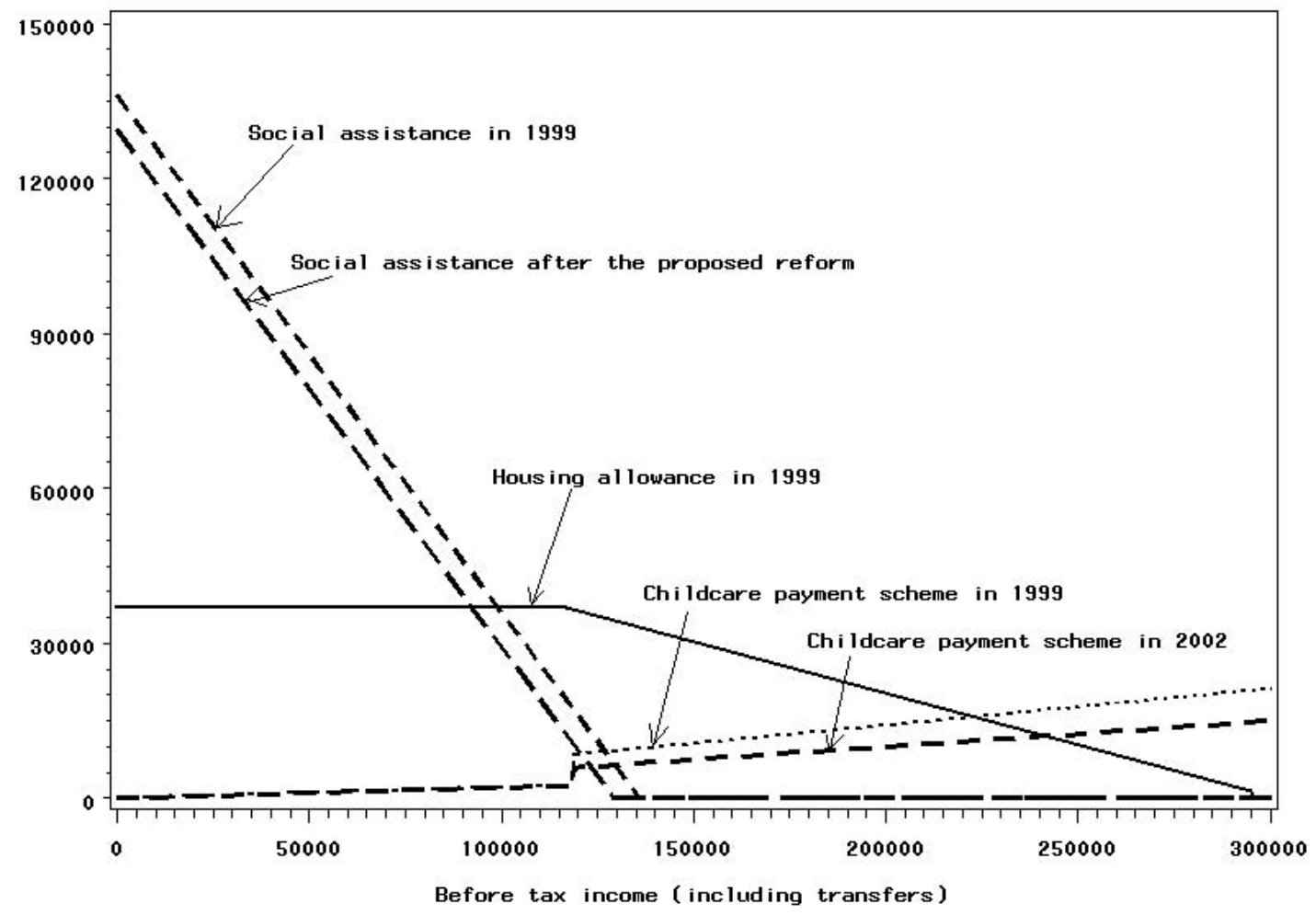

Figure 3. Means -tested subsides in Sweden (SEK).

Note: This figure is based on a single mother household with two children, aged 2 and 4, using an average housing-cost. 


\section{IZA Discussion Papers}

\begin{tabular}{|c|c|c|c|c|}
\hline No. & Author(s) & Title & Area & Date \\
\hline 877 & M.-S. Yun & Decomposing Differences in the First Moment & 3 & 09/03 \\
\hline 878 & $\begin{array}{l}\text { J. T. Addison } \\
\text { C. Schnabel } \\
\text { J. Wagner }\end{array}$ & $\begin{array}{l}\text { The Course of Research into the Economic } \\
\text { Consequences of German Works Councils }\end{array}$ & 3 & 09/03 \\
\hline 879 & $\begin{array}{l}\text { A. Constant } \\
\text { Y. Shachmurove }\end{array}$ & $\begin{array}{l}\text { Entrepreneurial Ventures and Wage Differentials } \\
\text { Between Germans and Immigrants }\end{array}$ & 1 & $09 / 03$ \\
\hline 880 & $\begin{array}{l}\text { W. Koeniger } \\
\text { A. Vindigni }\end{array}$ & $\begin{array}{l}\text { Employment Protection and Product Market } \\
\text { Regulation }\end{array}$ & 2 & $10 / 03$ \\
\hline 881 & R. A. Hart & $\begin{array}{l}\text { Worker-Job Matches, Job Mobility, and Real } \\
\text { Wage Cyclicality }\end{array}$ & 1 & $10 / 03$ \\
\hline 882 & $\begin{array}{l}\text { A. Lindbeck } \\
\text { D. J. Snower }\end{array}$ & The Firm as a Pool of Factor Complementarities & 5 & $10 / 03$ \\
\hline 883 & $\begin{array}{l}\text { S. Groeneveld } \\
\text { J. Hartog }\end{array}$ & $\begin{array}{l}\text { Overeducation, Wages and Promotions within } \\
\text { the Firm }\end{array}$ & 5 & $10 / 03$ \\
\hline 884 & $\begin{array}{l}\text { J. Masso } \\
\text { A. Heshmati }\end{array}$ & $\begin{array}{l}\text { The Optimality and Overuse of Labour in } \\
\text { Estonian Manufacturing Enterprises }\end{array}$ & 4 & $10 / 03$ \\
\hline 885 & $\begin{array}{l}\text { A. Constant } \\
\text { K. F. Zimmermann }\end{array}$ & $\begin{array}{l}\text { The Dynamics of Repeat Migration: A Markov } \\
\text { Chain Analysis }\end{array}$ & 1 & $10 / 03$ \\
\hline 886 & $\begin{array}{l}\text { J. J. Dolado } \\
\text { M. Jansen } \\
\text { J. F. Jimeno }\end{array}$ & $\begin{array}{l}\text { On-the-Job Search in a Matching Model with } \\
\text { Heterogenous Jobs and Workers }\end{array}$ & 1 & $10 / 03$ \\
\hline 887 & $\begin{array}{l}\text { B. Irlenbusch } \\
\text { D. Sliwka }\end{array}$ & $\begin{array}{l}\text { Transparency and Reciprocal Behavior in } \\
\text { Employment Relations }\end{array}$ & 7 & $10 / 03$ \\
\hline 888 & W. Koeniger & $\begin{array}{l}\text { Collective Dismissal Cost, Product Market } \\
\text { Competition and Innovation }\end{array}$ & 3 & $10 / 03$ \\
\hline 889 & D. E. Wildasin & $\begin{array}{l}\text { Fiscal Policy, Human Capital, and Canada-US } \\
\text { Labor Market Integration }\end{array}$ & 2 & $10 / 03$ \\
\hline 890 & $\begin{array}{l}\text { M. Bratti } \\
\text { L. Mancini }\end{array}$ & $\begin{array}{l}\text { Differences in Early Occupational Earnings of } \\
\text { UK Male Graduates by Degree Subject: } \\
\text { Evidence from the 1980-1993 USR }\end{array}$ & 6 & $10 / 03$ \\
\hline 891 & $\begin{array}{l}\text { L. Flood } \\
\text { E. Pylkkänen } \\
\text { R. Wahlberg }\end{array}$ & $\begin{array}{l}\text { From Welfare to Work: Evaluating a Proposed } \\
\text { Tax and Benefit Reform Targeted at Single } \\
\text { Mothers in Sweden }\end{array}$ & 6 & $10 / 03$ \\
\hline
\end{tabular}

An updated list of IZA Discussion Papers is available on the center's homepage www.iza.org. 